\title{
Antibacterial activity of trimetal (CuZnFe) oxide nanoparticles
}

This article was published in the following Dove Press journal:

International Journal of Nanomedicine

\author{
Khalid E Alzahrani ${ }^{1,2}$ \\ Abdurahman A Niazy ${ }^{3}$ \\ Abdullah M Alswieleh ${ }^{4}$ \\ Rizwan Wahab ${ }^{5}$ \\ Ahmed M El-Toni ${ }^{2}$ \\ Hamdan S Alghamdi ${ }^{3}$ \\ 'Department of Physics and \\ Astronomy, King Saud University, \\ Riyadh, Kingdom of Saudi Arabia; \\ ${ }^{2}$ King Abdullah Institute for \\ Nanotechnology, King Saud University, \\ Riyadh, Kingdom of Saudi Arabia; \\ ${ }^{3}$ Prince Naif Health Research \\ Center, Molecular and Cell Biology \\ Laboratory, College of Dentistry, King \\ Saud University, Riyadh, Kingdom \\ of Saudi Arabia; ${ }^{4}$ Department of \\ Chemistry, College of Science, King \\ Saud University, Riyadh, Kingdom \\ of Saudi Arabia; ${ }^{5}$ Department of \\ Zoology, College of Science, King \\ Saud University, Riyadh, Kingdom \\ of Saudi Arabia
}

Background: The increasing resistance of pathogenic bacteria to antibiotics is a challenging worldwide health problem that has led to the search for new and more efficient antibacterial agents. Nanotechnology has proven to be an effective tool for the fight against bacteria.

Methods: In this paper, we present the synthesis and traits of trimetal ( $\mathrm{CuZnFe})$ oxide nanoparticles (NPs) using X-ray diffraction, high-resolution transmission electron microscopy, and energy dispersive $\mathrm{x}$-ray spectroscopy. We evaluated the antibacterial activity of these NPs against gram-negative Escherichia coli and gram-positive Enterococcus faecalis and then compared it to that of their pure single-metal oxide components $\mathrm{CuO}$ and $\mathrm{ZnO}$.

Results: Our study showed that the antibacterial activity of the trimetal oxide NPs was greater against $E$. coli than against $E$. faecalis. Overall, the antimicrobial effect of trimetal NPs is between those of pure $\mathrm{ZnO}$ and $\mathrm{CuO}$ nanoparticles, which may mean that their cytotoxicity is also between that of pure $\mathrm{ZnO}$ and $\mathrm{CuO}$ NPs, making them potential antibiotics. However, the cytotoxicity of trimetal NPs to mammalian cells needs to be verified.

Conclusion: The combination of three metal oxide $\mathrm{NPs}\left(\mathrm{ZnO}, \mathrm{CuO}\right.$, and $\left.\mathrm{Fe}_{2} \mathrm{O}_{3}\right)$ in one multimetal $(\mathrm{CuZnFe})$ oxide NPs will enhance the therapeutic strategy against a wide range of microbial infections. Bacteria are unlikely to develop resistance against this new NP because bacteria must go through a series of mutations to become resistant to the trimetal oxide NP. Therefore, this NP can combat existing and emerging bacterial infections.

Keywords: nanotechnology, antibacterial agents, nanoparticles, trimetal nanoparticles, Escherichia coli, Enterococcus faecalis

\section{Introduction}

Bacterial infections are major challenges for the medical field and have become a serious threat to human health and lives. An increasing number of species of bacteria have developed resistance against most common antibiotics from the misuse of these drugs. ${ }^{1}$ The list of drug-resistant bacteria has increased dramatically, for example, Enterobacter cloacae is sulfonamide- and methicillin-resistant, Staphylococcus aureus is vancomycin-resistant, Mycobacterium tuberculosis is resistant to multiple drugs, and Streptococcus pyogenes and Acinetobacter baumannii are macrolide-resistant. ${ }^{2-4}$ Generally, biofilm-growing bacteria are highly resistant to antibacterial drugs and the host immune system, although the exact mechanisms underlying such resistance are still not fully understood. ${ }^{5,6}$ Biofilm is a structured community of bacteria embedded in a self-produced extracellular matrix of proteins, polysaccharides, and DNA. Consequently, infections involving biofilm formation are chronic and difficult to treat. Therefore, there is an urgent need to find alternative therapeutic approaches for overcoming the increasing resistance of bacteria to current antibiotics. 
Controlling the growth of bacterial biofilms using nanoparticles (NPs) has become the center of attention in the medical field. The use of NPs is a promising therapeutic strategy for overcoming the increasing emergence of multidrug-resistant bacteria. Although the antimicrobial effects of NPs have been verified using different types of NPs on various bacterial species, the bactericidal mechanisms of NPs are still being investigated. Several factors such as the physiochemical properties of NPs and the bacterial species involved might play important roles in the antibacterial activity of NPs. Some bacterial species are more sensitive to particular NPs than are others. Ag NPs are more efficient than $\mathrm{Cu}$ NPs against Escherichia coli and S. aureus, whereas Bacillus subtilis showed more susceptibility to $\mathrm{Cu}$ NPs than to Ag NPs. ${ }^{7}$ Titanium dioxide NPs exhibited greater antibacterial activity against $E$. coli than against Salmonella typhimurium. ${ }^{8}$ Dizaj et $\mathrm{al}^{9}$ showed that Ag NPs have a greater antibacterial effect on Streptococcus mutans than do $\mathrm{ZnO}$ and Au NPs. The sensitivity of bacteria to NPs is related to the species whereby the cell structure of the bacteria influences its tolerance to NPs. Vancomycin-resistant bacteria (eg, Enterococci) develop an additional outer membrane that covers the cellular surface and protects the bacterium from the vancomycin. Vancomycin-capped Au NPs can penetrate the outer cell membrane, allowing the vancomycin to access the cellular surface. ${ }^{10}$ Poly(vinyl alcohol)-coated $\mathrm{ZnO}$ NPs can kill bacterial cells by inducing oxidative stress. ${ }^{11}$ Furthermore, the size of the NP plays an important role in its toxicity. Hayden et $\mathrm{al}^{12}$ studied the effect of size reduction on the antibacterial efficiency of Au NPs and found that $2 \mathrm{~nm} \mathrm{Au}$ NPs are more toxic to B. subtilis than $6 \mathrm{~nm}$ Au NPs.

Several types of metal and metal oxide NPs such as $\mathrm{CuO}$, $\mathrm{CaO}, \mathrm{Ag}$ and $\mathrm{Ag}_{2} \mathrm{O}, \mathrm{Au}, \mathrm{ZnO}$, and $\mathrm{MgO}$ have been investigated for their antibacterial effects. Diverse studies revealed that $\mathrm{ZnO}$ NPs exhibit a wide spectrum of antibacterial activities toward various gram-negative and gram-positive bacteria. ${ }^{13}$ For example, they are very efficient at inhibiting the growth of gram-negative E. coli and Pseudomonas aeruginosa and grampositive $S$. aureus and B. subtilis. ${ }^{14-17}$ The antibacterial effect of $\mathrm{ZnO}$ NPs on $S$. mutans was compared with that of other NPs such as Ag and Au and it was observed that ZnO NPs had the lowest bactericidal activity. ${ }^{18}$ However, many toothpastes contain $\mathrm{Zn}$ to combat dental plaque that is formed by bacteria such as $S$. mutans. ${ }^{19}$ The antimicrobial activities of ZnO NPs have been found to be affected by the size and concentration of the NPs but the bactericidal mechanisms of $\mathrm{Zn}$ and $\mathrm{ZnO}$ NPs still are unknown. Recently, ZnO NPs have begun to be used in food packaging, although there is some concern about the potential impact of NPs on the health of consumers.
According to some studies, $\mathrm{ZnO}$ NPs exhibit minimal toxicity to human cells. ${ }^{20}$ Heng et $\mathrm{al}^{21}$ demonstrated the cytotoxic effect of $\mathrm{ZnO}$ NPs on human bronchial epithelium cells, but the effect of $\mathrm{ZnO}$ NPs on other human cells has not been confirmed yet and additional research is needed. In addition, Ingle et $\mathrm{al}^{22}$ has reported interesting data on the antimicrobial effect of $\mathrm{Cu}$ and $\mathrm{CuO}$ NPs. Das et $\mathrm{al}^{23}$ demonstrated that nanostructured $\mathrm{Cu}$ efficiently inhibits the growth of $S$. mutans, E. coli, and $B$. subtilis. $\mathrm{Xu}$ et $\mathrm{al}^{24}$ studied the susceptibility of gram-positive and gram-negative bacteria to $\mathrm{Cu}$ NPs and found that gramnegative bacteria are more susceptible. Like other NPs, Cu NPs showed size-dependent bactericidal activity. Several in vivo and in vitro studies on the toxicity of Cu NPs to human cells showed that they can cause irreversible damage. ${ }^{25-27}$

The main aim of our study was to combine the strong antibacterial activity of $\mathrm{ZnO}$ and $\mathrm{CuONPs}$ with that of $\mathrm{Fe}_{2} \mathrm{O}_{3}$. $\mathrm{ZnO}$ and $\mathrm{CuO}$ NPs showed the most antibacterial activity against various bacterial species, while $\mathrm{Fe}_{2} \mathrm{O}_{3} \mathrm{NPs}$ showed the least toxicity. ${ }^{17}$ The combination of the three metal oxide NPs formed a new nanostructured $\mathrm{CuZnFe}$ oxide NP, called a trimetal oxide NP. To our best knowledge, multi-metal oxide NPs are usually prepared using complicated methods. ${ }^{28}$ In the present study, we report, for the first time, the synthesis of $\mathrm{CuZnFe}$ oxide NPs using inexpensive chemicals and very easy solution process to form good quality nanostructures for large-scale production. This composite NP has the potential to control a wider range of bacterial infections compared to single NP material. Although ZnO NPs are relatively less toxic to human cells than $\mathrm{CuO}$ NPs in aqueous solution, they tend to aggregate and form large flocculates that decrease their antibacterial activity. ${ }^{29}$ The stability of $\mathrm{ZnO}$ NPs in aqueous media may be improved by combining them with $\mathrm{Fe}_{2} \mathrm{O}_{3} \mathrm{NPs}_{\text {. }} \mathrm{Fe}_{2} \mathrm{O}_{3}$ may provide some magnetic properties to these NPs resulting in their use in several additional applications. We tested the antibacterial activities of the $\mathrm{CuZnFe}$ oxide NP against gramnegative E. coli and gram-positive Enterococcus faecalis. Bacteria are unlikely to develop resistance against this new NP because bacteria must go through a series of mutations to become resistant to the trimetal oxide NP. Therefore, this NP can combat existing and emerging bacterial infections.

\section{Materials and methods Synthesis of $\mathrm{ZnO}$ NPs}

$\mathrm{ZnO}$ NPs were synthesized using zinc acetate dihydrate $\left[\mathrm{Zn}\left(\mathrm{CH}_{3} \mathrm{COO}\right)_{2} \cdot 2 \mathrm{H}_{2} \mathrm{O}\right]$ and n-propyl amine $\left[\mathrm{CH}_{3}-\left(\mathrm{CH}_{2}\right)_{2}-\right.$ $\mathrm{NH}_{2}$ ], purchased from Sigma-Aldrich Corporation (St Louis, MO, USA) and used without further purification. In a typical experiment, $\sim 20 \mathrm{~mL}$ of n-propyl amine and $0.3 \mathrm{M}$ zinc acetate 
dihydrate were dissolved in $100 \mathrm{~mL}$ of methanol (MeOH). The obtained solution was stirred for 30 min for complete dissolution. The $\mathrm{pH}$ of the solution, measured using an expandable ion analyzer (Cole Parmer, Vernon Hills, IL, USA), was 12.2. After complete dissolution, the mixture was transferred to a three-necked refluxing pot and refluxed at $65^{\circ} \mathrm{C}$ for $6 \mathrm{~h}$. After $6 \mathrm{~h}$, a white precipitate was observed in the double-necked refluxing pot. A specialized temperature controller measured and controlled the refluxing temperature. The white powder was washed several times with $\mathrm{MeOH}$, ethanol (EtOH), and acetone and dried at room temperature in a glass Petri dish. The obtained powder was characterized by its structural and chemical properties.

\section{Synthesis of CuO NPs}

$\mathrm{CuO}$ NPs were synthesized using copper acetate hydrate $\left[\mathrm{Cu}\left(\mathrm{CH}_{3} \cdot \mathrm{COO}\right)_{2} \cdot \mathrm{H}_{2} \mathrm{O}\right]$, n-propyl amine $\left[\mathrm{CH}_{3}-\left(\mathrm{CH}_{2}\right)_{2}-\mathrm{NH}_{2}\right]$, and sodium hydroxide $(\mathrm{NaOH})$, purchased from SigmaAldrich and used as received. In a typical experiment, $0.3 \mathrm{M}$ of copper acetate hydrate and $20 \mathrm{~mL}$ of n-propyl amine were mixed in $100 \mathrm{~mL}$ of $\mathrm{MeOH}$ with constant stirring, after which the solution turned blue. $\mathrm{NaOH}(0.1 \mathrm{M})$ was mixed into the solution in steps and shaken each time to ensure complete mixing. After adding the $\mathrm{NaOH}$, the $\mathrm{pH}$ of the solution, checked via a pH meter (Cole Parmer), was 12.01 because of the increased basicity of the solution. The solution was transferred to a double-necked refluxing pot and refluxed at $\sim 90^{\circ} \mathrm{C}$ for $6 \mathrm{~h}$. As the temperature of the solution increased, the color changed from blue to dark brown to black. After the reaction was complete, the product was centrifuged at 3,000 rpm for $3 \mathrm{~min}$ and washed repeatedly with $\mathrm{MeOH}, \mathrm{EtOH}$, and acetone to remove the intermediate by-products. The material was dried at room temperature in a glass Petri dish and utilized for further chemical, morphological, and biological studies.

\section{Formation of $\mathrm{CuZnFe}$ oxide NPs}

Trimetal CuZnFe oxide NPs were formed by dissolving $0.3 \mathrm{M}$ of zinc acetate dihydrate $\left[\mathrm{Zn}\left(\mathrm{CH}_{3} \mathrm{COO}\right)_{2} \cdot 2 \mathrm{H}_{2} \mathrm{O}\right], 0.3 \mathrm{M}$ of copper acetate hydrate $\left[\mathrm{Cu}\left(\mathrm{CH}_{3} \mathrm{COO}\right)_{2} \cdot \mathrm{H}_{2} \mathrm{O}\right]$, and $0.3 \mathrm{M}$ of iron nitrate nonahydrate $\left[\mathrm{Fe}\left(\mathrm{NO}_{3}\right)_{3} \cdot 9 \mathrm{H}_{2} \mathrm{O}\right]$ in $300 \mathrm{~mL}$ of $\mathrm{MeOH}$ and stirring constantly for $30-40 \mathrm{~min}$. When the solution was completely dissolved, $60 \mathrm{~mL}$ of n-propyl amine $\left[\mathrm{CH}_{3}-\left(\mathrm{CH}_{2}\right)_{2}-\mathrm{NH}_{2}\right]$ was added, followed by the dropwise addition of $0.1 \mathrm{M}$ of $\mathrm{NaOH}$ to increase the basicity of the solution. The $\mathrm{pH}$ of the solution, checked via a $\mathrm{pH}$ meter (Cole Parmer), was 12.61. The mixture was transferred to a double-necked refluxing pot and refluxed at $\sim 90^{\circ} \mathrm{C}$ for $6 \mathrm{~h}$ to obtain a red precipitate. The precipitate was washed several times with $\mathrm{MeOH}, \mathrm{EtOH}$, and acetone to remove ionic impurities and dried at room temperature. The material was studied for its structural and chemical properties.

\section{Characterization of NPs}

The phase, crystallinity, and size of the prepared nanostructures were characterized by their x-ray diffraction (XRD) pattern (Rigaku, Tokyo, Japan) obtained with $\mathrm{Cu}_{\mathrm{K} \alpha}$ radiation $(\lambda=1.54178 \AA)$ in the $20^{\circ}-80^{\circ}$ range at a scan speed of $6 \% \mathrm{~min}$, an accelerating voltage of $40 \mathrm{kV}$, and current of $40 \mathrm{~mA}$. The morphology of the prepared nanostructures was analyzed using transmission electron microscopy (TEM, 200 kV; Hitachi, Tokyo, Japan). For TEM analysis of the nanostructures, NP powder was sonicated in EtOH for 10-20 min. Then a $\mathrm{C}$-coated $\mathrm{Cu}$ grid (400 mesh) was dipped into the solution and dried at room temperature for morphological analysis.

\section{In vitro experimental procedures}

For the gram-positive bacterium, we chose E. faecalis because it can cause life-threatening infections in humans and shows a high level of resistance to antibiotics. In addition, E. faecalis has been found to be associated with up to $90 \%$ of the cases of chronic infection in teeth that underwent root canal treatment. For the gram-negative and facultative anaerobic bacterium, we chose E. coli, which can cause serious food poisoning and is occasionally responsible for food contamination.

\section{Cell death analysis}

The method used to measure bacterial cell death was previously described. ${ }^{30,31}$ Briefly, cell death of E. faecalis and E. coli was analyzed using fresh culture grown in $25 \mathrm{~mL}$ of nutrient broth (NB; yeast extract $2 \mathrm{~g} / \mathrm{l}$, peptone $5 \mathrm{~g} / \mathrm{l}$, $\mathrm{NaCl} 5 \mathrm{~g} / \mathrm{l})$ in a $50-\mathrm{mL}$ conical flask until the stationary phase showed no cell growth. The density of E. faecalis and E. coli was measured using an Eppendorf BioPhotometer Plus spectrophotometer (Thomas Scientific, Swedesboro, NJ, USA). A portion ( $5 \mathrm{~mL}$ ) of the culture was transferred to a new sterile $20 \mathrm{~mL}$ conical flask. The bacteria were then added to three conical flasks containing $\mathrm{Zn}, \mathrm{Cu}$, and $\mathrm{CuZnFe}$ oxide NPs at $150 \mu \mathrm{g} / \mathrm{mL}$ and to three control flasks that did not contain any NPs. The flasks were then placed in a shaking incubator and shaken at $220 \mathrm{rpm}$ for $5 \mathrm{~h}$ at $37^{\circ} \mathrm{C}$, after which $1 \mathrm{~mL}$ from each flask was used to measure the optical density at $595 \mathrm{~nm}$. The blank flasks contained $150 \mu \mathrm{g} / \mathrm{mL}$ of the corresponding NPs and media. The average of three readings was used for each NP. 


\section{Biofilm formation}

The aim of this part was to test the ability of the bacteria E. faecalis and E. coli to form a biofilm in the presence of $\mathrm{CuO}, \mathrm{ZnO}$, and $\mathrm{CuZnFe}$ oxide NPs. Microbial biofilm is the main method of overcoming a harsh environment and the host immune system. ${ }^{30} \mathrm{We}$ used the spectrophotometric assay method to study biofilm formation. The bacteria were grown in a 96-well plate in triplicate using NB. Each well contained either NB with no NPs or NB with $\mathrm{ZnO}, \mathrm{CuO}$, or $\mathrm{CuZnFe}$ oxide NPs at $150 \mu \mathrm{g} / \mathrm{mL}$. The plate was then incubated at $37^{\circ} \mathrm{C}$ for $48 \mathrm{~h}$ after being tightly sealed to prevent dehydration. The media in the plate were then poured into a designated waste container with $10 \%$ bleach. The plate was submerged in water to eliminate any excess media and was left to air dry. One-hundred twenty-five microliters of $0.1 \%$ crystal violet solution was added to each well and the plate was incubated at room temperature for $10 \mathrm{~min}$. The crystal violet solution was poured into the designated waste container. The plate was submerged in water to eliminate any excess solution and left to air dry. Next, $200 \mu \mathrm{L}$ of $100 \%$ $\mathrm{EtOH}$ was added to each well and the plate was incubated at room temperature for $15 \mathrm{~min}$. EtOH in each well was mixed by pipetting gently to evenly distribute the color. The plate was then read in a Synergy ${ }^{\mathrm{TM}}$ HT Multi-Mode microplate reader (BioTek, Winooski, VT, USA) at $\lambda=490 \mathrm{~nm}$.

\section{$\mathrm{CFU} / \mathrm{mL}$ analysis}

To test the ability of E. faecalis and $E$. coli to grow in the presence of the NPs, a viable cell count per milliliter was conducted using the colony-forming unit (CFU)/mL method. Bacterial cells $(1 \mathrm{~mL}$ ), grown overnight in $20 \mathrm{~mL}$ of $\mathrm{NB}$ (grown in a sterile $50 \mathrm{~mL}$ conical flask) and standardized to $1 \times 10^{5}$ cells, were mixed with $150 \mu \mathrm{g}$ of $\mathrm{ZnO}, \mathrm{CuO}$, and $\mathrm{CuZnFe}$ oxide NPs and then the mixture was added to $9 \mathrm{~mL}$ of sterile distilled water. The solution underwent serial dilution until a dilution of $1 \times 10^{-7}$ was obtained. NP-exposed samples and a control were streaked on four NB Petri dish plates each. The plates were then incubated overnight at $37^{\circ} \mathrm{C}$. Each sample was tested in triplicate and the average of the three results was used.

\section{Statistical analysis}

To compare the quantitative variables of the groups, we used the nonparametric Mann-Whitney test; $p<0.05$ was considered statistically significant.

\section{Results}

\section{Characterization of CuZnFe oxide NPs}

We used the XRD pattern, shown in Figure 1, to characterize the size, phase, and crystalline character of $\mathrm{CuZnFe}, \mathrm{ZnO}$, and $\mathrm{CuO}$ NPs. Comparison of the XRD patterns, in Figure 1, to the XRD patterns of the materials in the International

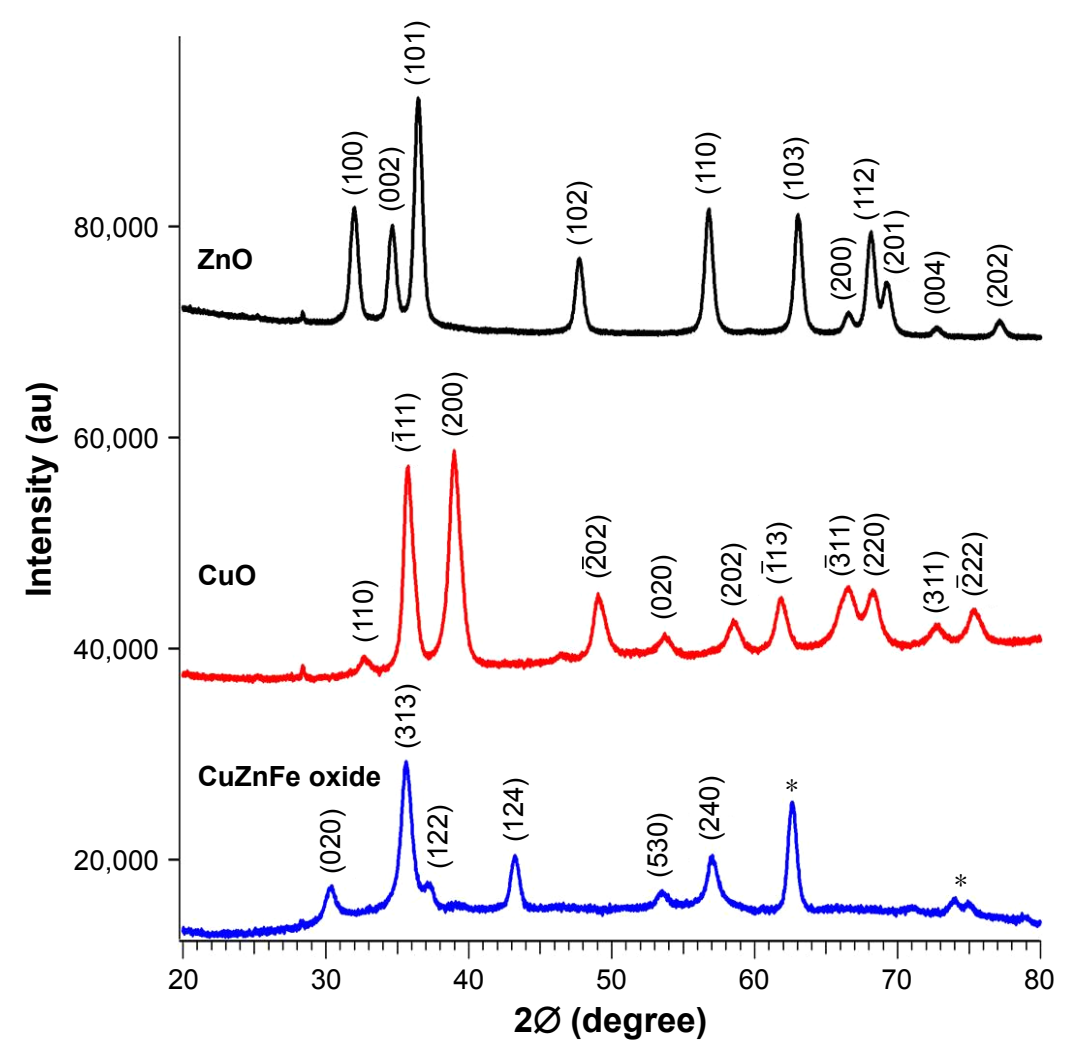

Figure I X-ray diffraction spectra of $\mathrm{ZnO}, \mathrm{CuO}$, and $\mathrm{CuZnFe}$ oxide nanoparticles. *Indicates that the peak is unidentified. 


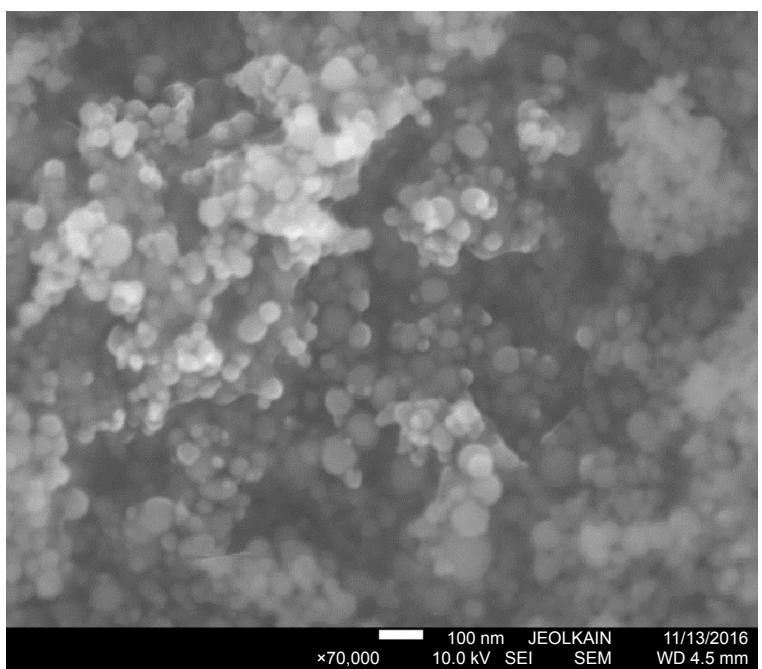

Figure 2 Scanning electron micrograph of the CuZnFe oxide nanoparticles.

Center for Diffraction Data identified our ZnO (black line), $\mathrm{CuO}$ (red line), and the trimetal $\mathrm{CuZnFe}$ oxide NPs (blue line) as $\mathrm{ZnO}$ (JCPDS card No 36-1451), CuO (JCPDS card No 05-066), and trimetal CuZnFe oxide (JCPDS card No 07-0392), respectively. However, three unidentified peaks were observed on the XRD spectrum of the $\mathrm{CuZnFe}$ oxide NPs. These peaks can be attributed to the complex formation of nanostructures in the mixed composite. The size of the crystallite can be calculated from XRD spectra using the Scherrer formula; $D=k \lambda / \beta \cos \theta$. The average size of the crystallite of the $\mathrm{CuZnFe}$ oxide NPs was calculated to be $23 \mathrm{~nm}$, where $k=0.9, \lambda=0.1541$, and $\beta$ is the full width at half-maximum of the peak at $\theta$.

The morphology of the CuZnFe oxide NPs was characterized using scanning electron microscopy (SEM) and highresolution TEM (HRTEM). Representative images from SEM and HRTEM are shown in Figures 2 and 3, respectively. The $\mathrm{CuZnFe}$ oxide NPs are almost spherical and have a clear tendency to agglomerate, which is normal for NPs because of the strong interparticle interaction induced by high surface energy. The size of agglomerate was analyzed by dynamic light scattering (Zeta Nanosizer) and found to be in $128 \mathrm{~nm}$ range. The average size of $\mathrm{CuZnFe}$ oxide NPs, based on several HRTEM images taken at different angles, was estimated to be $42 \pm 2 \mathrm{~nm}$, whereas the average particle size based on XRD measurements was $19 \mathrm{~nm}$ smaller. The smaller size may be the result of the nanostructures merging together to form a larger molecule of mixed nanostructures. This is indicative of the presence of particle agglomeration, which is clarified by the HRTEM images of lattice fringes (Figure 3). The XRD calculation represents only the average single particle dimension for the bulk/powder nanostructures. The nanostructures were further assessed using energy dispersive x-ray spectroscopy (EDX), which is usually employed to map NPs based on their composition. Figure 4 shows the EDX spectrum of the mixed CuZnFe oxide NPs. The spectral peaks correspond to $\mathrm{Zn} \mathrm{Cu}, \mathrm{Fe}$, and $\mathrm{O}$, confirming the presence of elemental $\mathrm{Zn}, \mathrm{Cu}$, and ferrite, with $\mathrm{O}$, in the NPs. No other impurity related to other elements was exhibited in the spectrum, which further shows that the synthesized nanostructures were only the mixed metal oxide nanostructures used.

\section{Antibacterial activity of CuZnFe oxide NPs}

Metallic NPs like Ag, $\mathrm{Cu}, \mathrm{Au}, \mathrm{Ti}$, and $\mathrm{Zn}$ have proven effective against a wide range of bacterial species. $\mathrm{Zn}$ and $\mathrm{Cu}$ are widely used to combat microbial infections and have shown relatively less cytotoxicity. ${ }^{32}$ The size of NPs allows them to penetrate the cell wall of bacteria and interact with cellular elements. ${ }^{33}$ Therefore, the size of NPs may contribute to their bactericidal effect. The combination of the three metal oxides in the $\mathrm{CuZnFe}$ oxide NPs may enhance the therapeutic abilities of the NPs against a wide range of microbial infections.
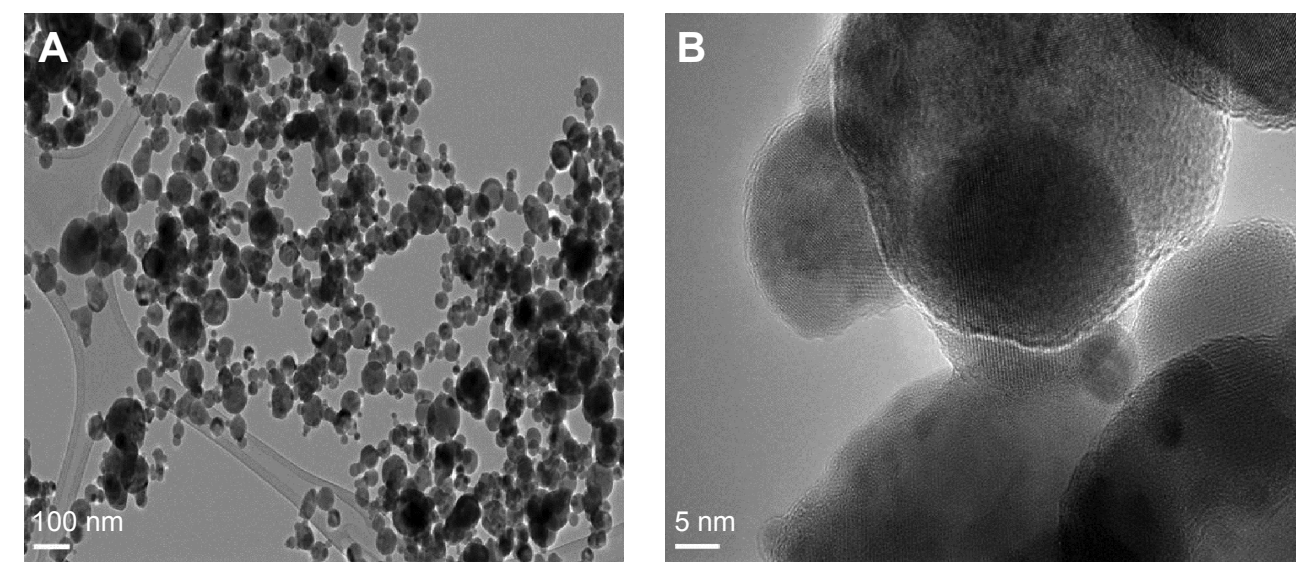

Figure 3 (A) High-resolution transmission electron microscope micrograph of the mixed CuZnFe oxide nanoparticles (NPs). (B) Atomic resolution of mixed CuZnFe oxide NPs. 


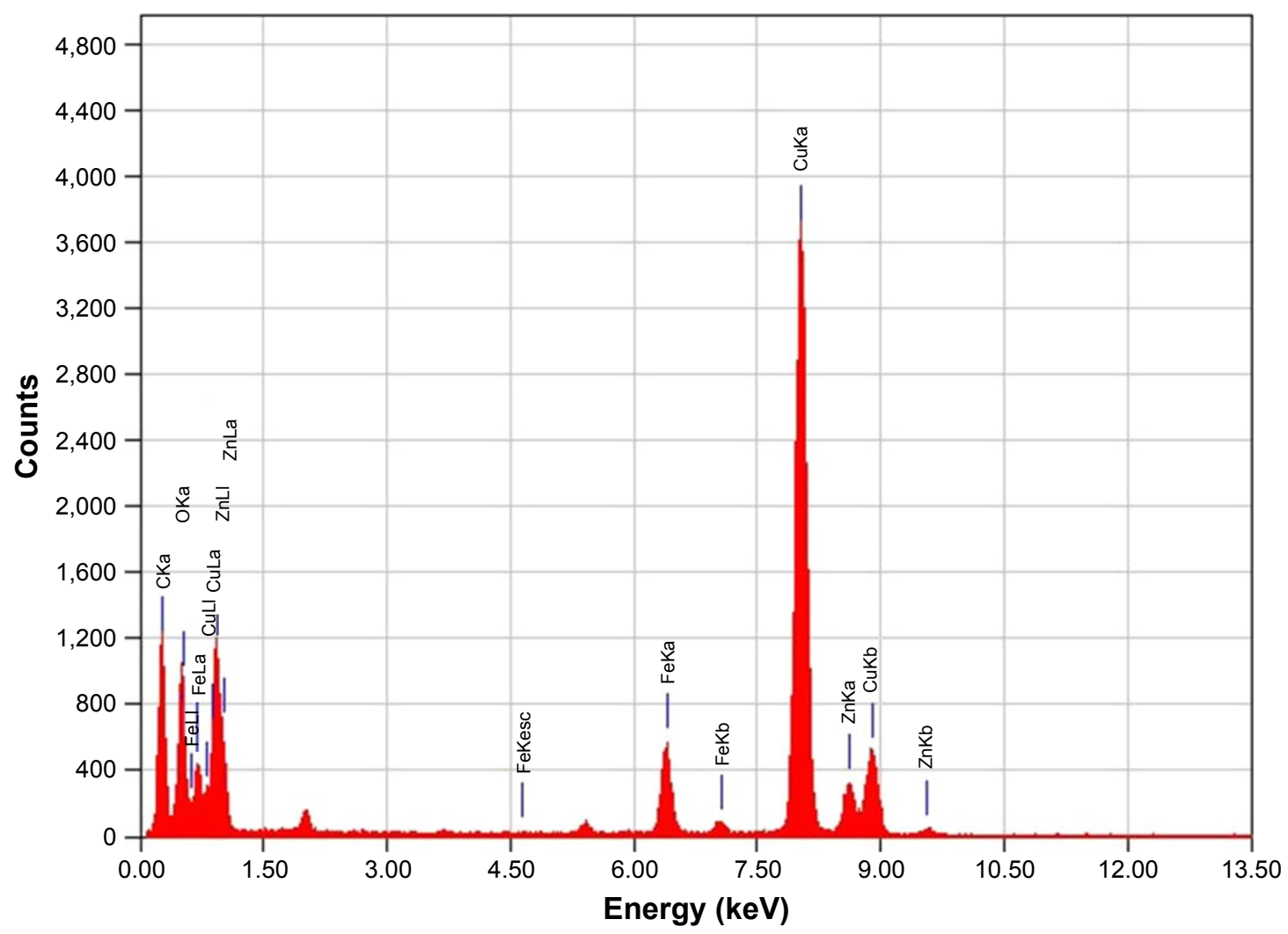

Figure 4 Energy dispersive $\mathrm{x}$-ray spectroscopy spectrum of mixed CuZnFe oxide nanoparticles.

Figure 5 compares the bactericidal effect of the trimetal $(\mathrm{CuZnFe})$ oxide NPs used in this study with that of pure $\mathrm{ZnO}$ and $\mathrm{CuO}$ NPs. The effect of $\mathrm{FeO}$ NPs against the bacterial cells was not investigated in this study. $\mathrm{FeO} \mathrm{NP}$ has been proven to have a low or no toxic effect on different bacterial species, in particular E. coli. ${ }^{17}$ The minimum concentration needed for the metal oxides to have a bactericidal effect on both bacterial species was at $150 \mu \mathrm{g} / \mathrm{mL}$. The cells not exposed to NPs showed no drop in cell density after $5 \mathrm{~h}$ of incubation, while cells exposed to NPs showed a significant drop in cell density, except E. coli (gram-negative) exposed to $\mathrm{CuO}$, where there was no cell death recorded. However, E. coli showed a $55 \%$ drop in cell density with exposure to $\mathrm{ZnO}$ and a nearly $85 \%$ drop in cell density with exposure to $\mathrm{CuZnFe}$ oxide NPs. E. faecalis (gram-positive) had the greatest drop in cell density when exposed to $\mathrm{CuO} \mathrm{NPs,} \mathrm{with}$ an $\sim 59 \%$ drop in live cells compared to an $\sim 25 \%$ drop in live cells with $\mathrm{ZnO}$ exposure and a 55\% drop with exposure to trimetal $(\mathrm{CuZnFe})$ oxide NPs.

The effect of trimetal (CuZnFe) oxide NPs on biofilm formation by both bacteria was proved, as shown in Figure 6 . However, $\mathrm{CuZnFe}$ oxide NPs had the least effect on biofilm formation when compared to that of $\mathrm{ZnO}$ and $\mathrm{CuO}$. There was an $\sim 50 \%$ reduction in biofilm formation by $E$. coli in the presence of $\mathrm{CuZnFe}$ oxide NPs, while the presence of $\mathrm{ZnO}$ and $\mathrm{CuO}$ NPs caused an $\sim 65 \%$ drop in biofilm formation by E. coli compared to control group. E. faecalis showed only a $26 \%$ drop in biofilm formation in the plate containing $\mathrm{CuZnFe}$ oxide NPs but a $62 \%$ and $40 \%$ drop in biofilm formation with $\mathrm{ZnO}$ and $\mathrm{CuO} \mathrm{NPs}$, respectively.

The growth of E. faecalis and E. coli on a nutrient agar was observed directly using a light microscope (Figure 7). This method is a useful and simple way to observe overnight growth of microbes without the presence of NPs or with $150 \mu \mathrm{g} / \mathrm{mL}$ of $\mathrm{ZnO}, \mathrm{CuO}$, or $\mathrm{CuZnFe}$ oxide NPs, and their effect on the CFU/mL count. Figure 8 presents the measurements of CFUs, indicating the antibacterial activity of $\mathrm{CuZnFe}$ oxide NPs. The viability of E. faecalis and E. coli was reduced by $40 \%$ and $38 \%$, respectively, in the presence of $\mathrm{CuZnFe}$ oxide NPs. However, $\mathrm{CuO}$ NPs had almost no effect on $E$. coli, whereas they reduced the viability of E. faecalis by $70 \%$. E. faecalis and E. coli showed a decrease in cell viability of $22 \%$ and $75 \%$, respectively, after being exposed to $\mathrm{ZnO}$ NPs.

\section{Discussion}

Trimetallic nanoparticles were successfully synthesized by combining $\mathrm{ZnO}$ and $\mathrm{CuO}$ NPs with that of $\mathrm{Fe}_{2} \mathrm{O}_{3}$. 


\section{A Cell death analysis for E. faecalis}

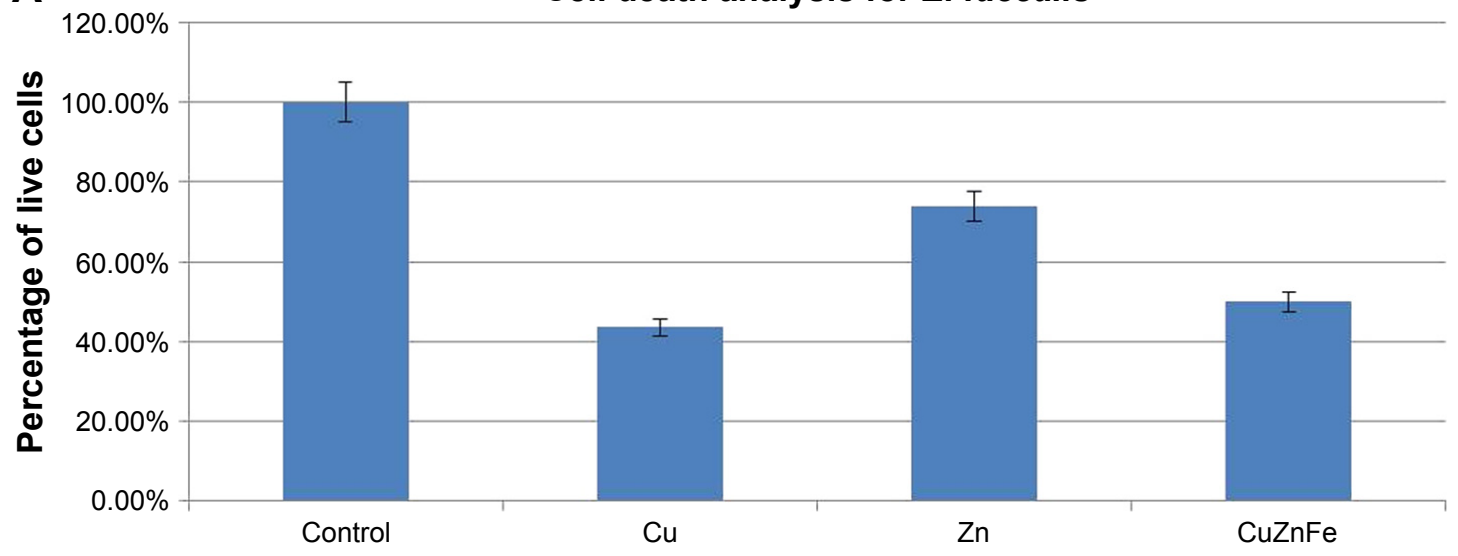

B Cell death analysis for $E$. coli

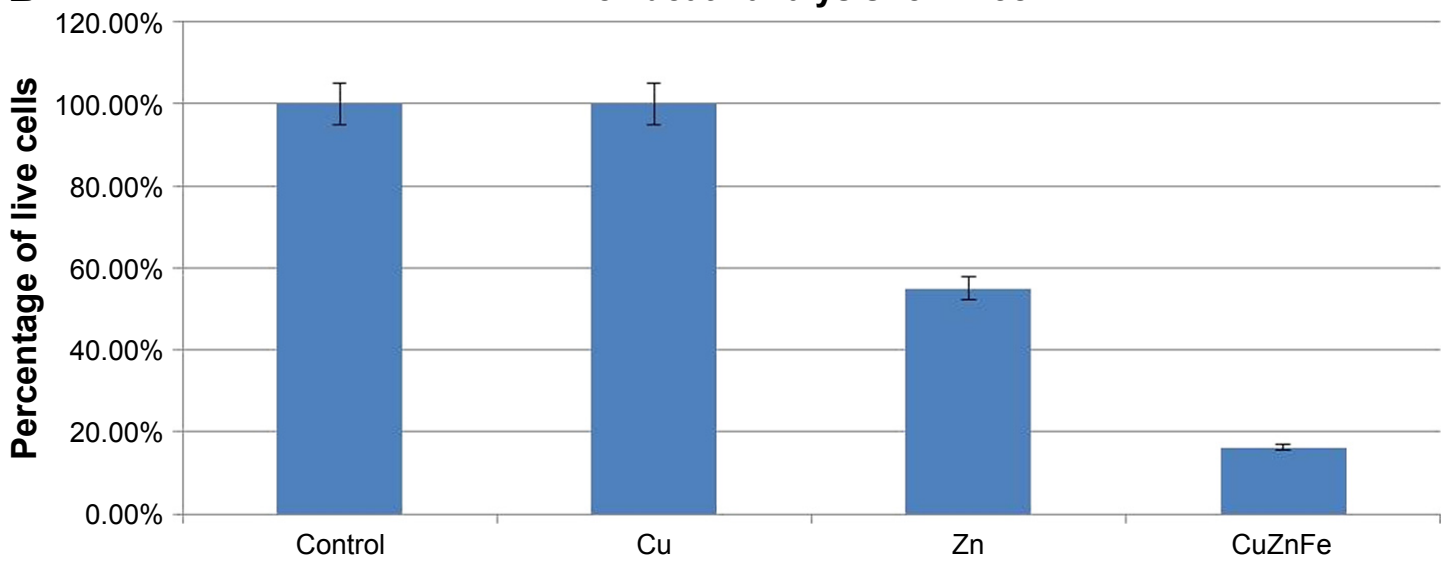

Figure 5 Percentage of live (A) Enterococcus faecalis (E. faecalis) cells and (B) Escherichia coli (E. coli) cells after $5 \mathrm{~h}$ of exposure to I50 $\mu \mathrm{g} / \mathrm{mL}$ of metal oxide nanoparticles. Cells were grown in nutrient broth.

The combination of the three metal oxide NPs formed a new nanostructured $\mathrm{CuZnFe}$ oxide NP. In the present study, we used inexpensive chemicals and a very easy process for fabrication of high-quality trimetal $(\mathrm{CuZnFe})$ oxide NPs. Multimetal oxide NPs are usually prepared using complicated methods. Based on the synthesis of $\mathrm{CuZnFe}$ oxide NPs, the use of metal salt of acetate and amine, in the current study, was due to that the acetate and amine can be easily dissociated in solution due to the breaking of hydrogen bonds at the time of refluxing of solution resulting in reaction with the other metal compound. This will easily react with the metal acetate $\left(\mathrm{MCH}_{3} \mathrm{COO}-\right)$ group initially. In solution, the metal ions ( $\mathrm{M}=\mathrm{Cu}^{2+}, \mathrm{Fe}^{2 / 3+}$ and $\mathrm{Zn}^{2+}$ ions) react with n-propyl-amine group to form a metal complex $\left(\mathrm{MN}-\left(\mathrm{CH}_{2}\right)_{2}-\mathrm{CH}_{3}\right)$. When the refluxing temperatures increase, the hydroxyl $\left(\mathrm{OH}^{-}\right)$ions from the used solvent methanol react with this metal complex and the metal ions from the complex decomposes, and then react to the hydroxyl $\left(\mathrm{OH}^{-}\right)$ions to form metal hydroxide $\left[\mathrm{M}(\mathrm{OH})_{2}\right]$. At higher refluxing temperature, hydroxide molecules change into metal oxide and water molecules.
The by-products of the reaction $\left[\left(\mathrm{CH}_{3}\right)_{2} \mathrm{~N}-\left(\mathrm{CH}_{2}\right)_{2}-\mathrm{CH}_{3}\right.$, $\mathrm{CH}_{3} \mathrm{COOH}$ and water molecule] were leached out during centrifugation of the product. ${ }^{34,35}$

Antibacterial activities of $\mathrm{CuZnFe}$ oxide NPs were tested against gram-negative $E$. coli and gram-positive $E$. faecalis. $\mathrm{CuZnFe}$ oxide NPs had an effect on both bacterial cells by reducing their viability and their ability to synthesize biofilm. Over the last few decades, bacterial resistance has challenged scientists to develop novel antimicrobial agents. Among them, metal NPs have shown strong antibacterial activity in several studies. ${ }^{2,3,9}$ Importantly, it is hypothesized that metal NPs might have the potential to control bacterial resistance because NPs target multiple biomolecules at once. ${ }^{8,9}$ However, the effect of metal oxide NPs on bacterial growth varies widely among bacterial species and even among strains of the same species. ${ }^{7,17,20}$ Based on the cell wall structure, bacterial cells can be divided into two distinct types: grampositive and gram-negative. Gram-positive bacteria have a thicker layer of peptidoglycan in their cell wall than that of gram-negative bacteria. However, gram-negative bacteria 


\section{A}

Biofilm formation E. faecalis

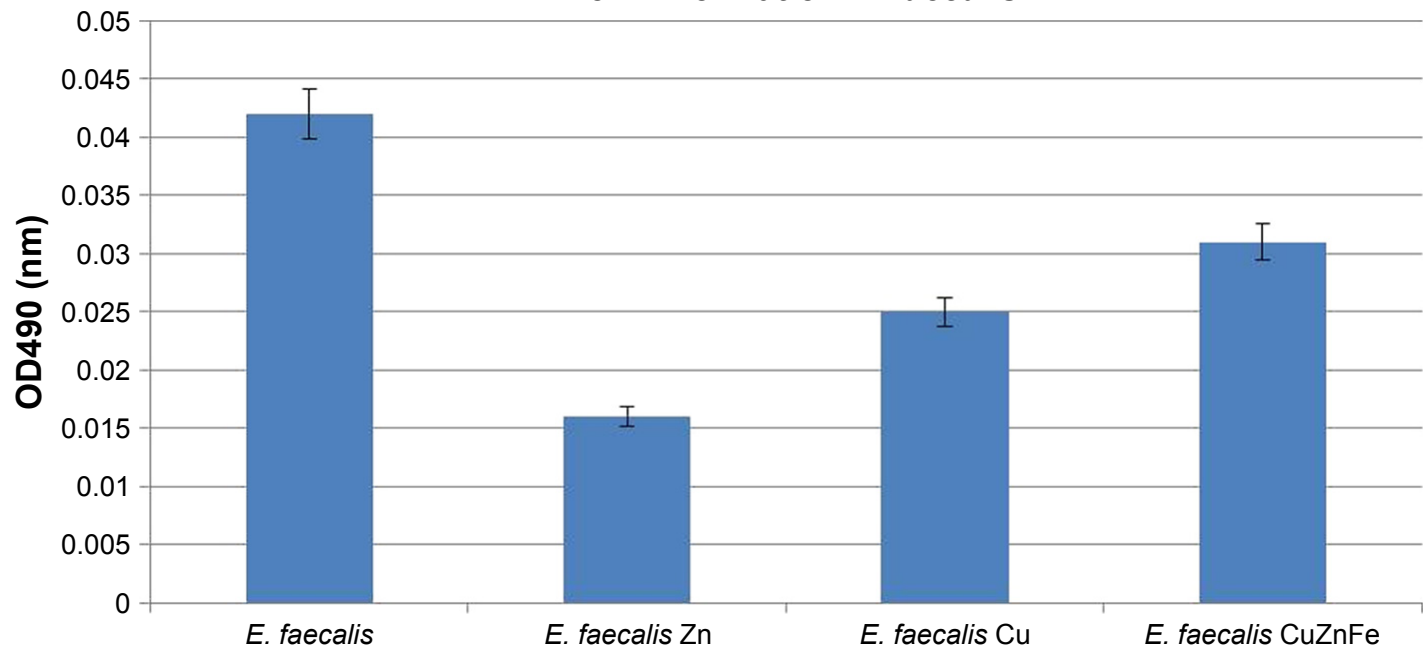

B

Biofilm formation E. coli

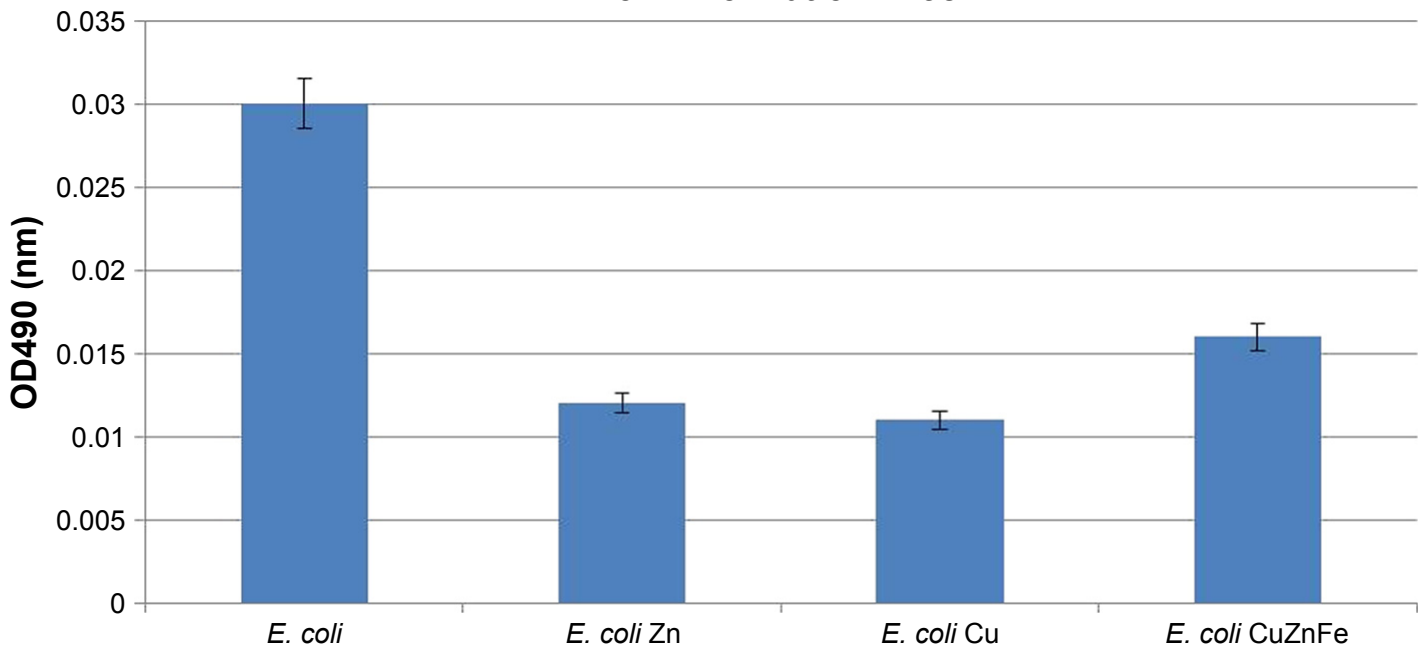

Figure 6 Ability of (A) Enterococcus faecalis (E. faecalis) and (B) Escherichia coli (E. coli) in nutrient broth to form biofilm after incubation with $150 \mu \mathrm{g} / \mathrm{mL}$ of metal nanoparticles as demonstrated by absorbance at $490 \mathrm{~nm}$ wavelength in a spectrophotometric reading.
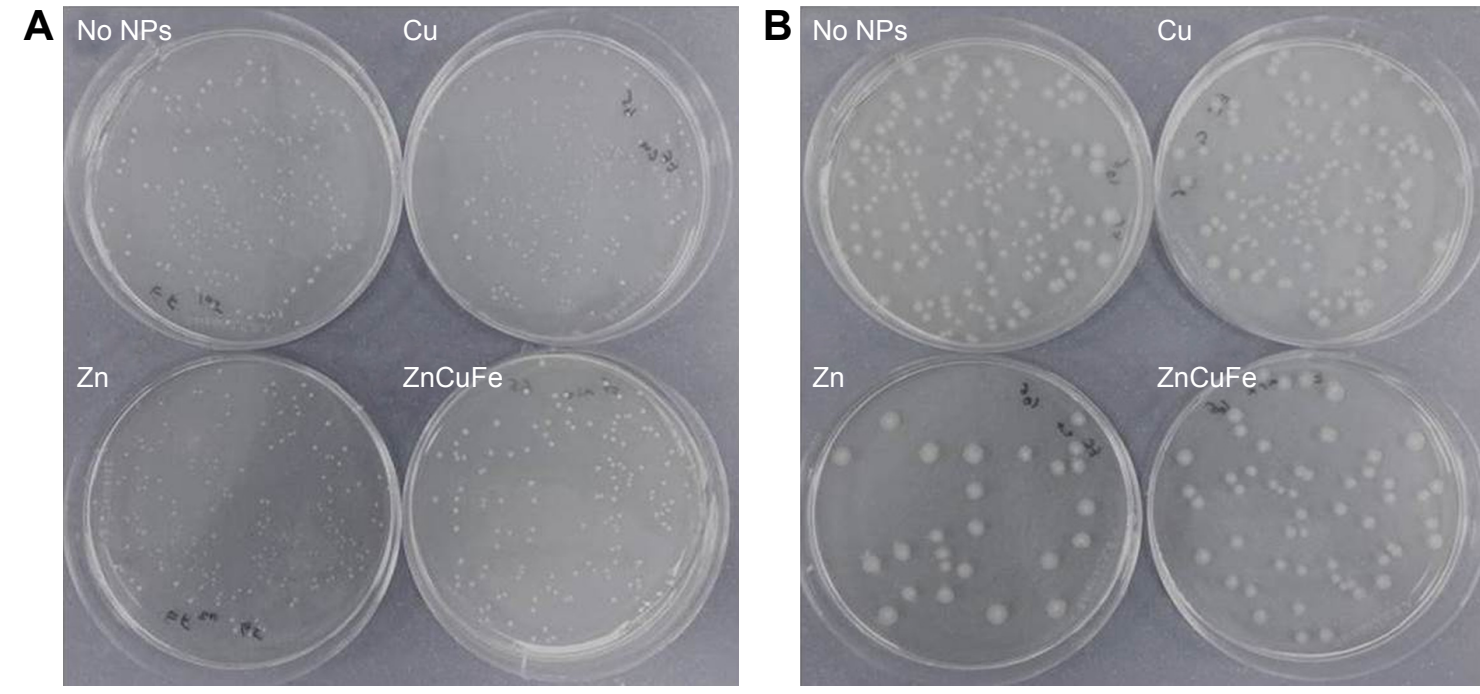

Figure 7 Representative images of overnight growth of microbes on nutrient agar with no nanoparticles (NPs) or with I50 $\mu g / \mathrm{mL}$ of $\mathrm{ZnO}$, CuO, or CuZnFe oxide NPs and their effect on the colony-forming unit/mL count: (A) Enterococcus faecalis, (B) Escherichia coli. 
A

E. faecalis CFU

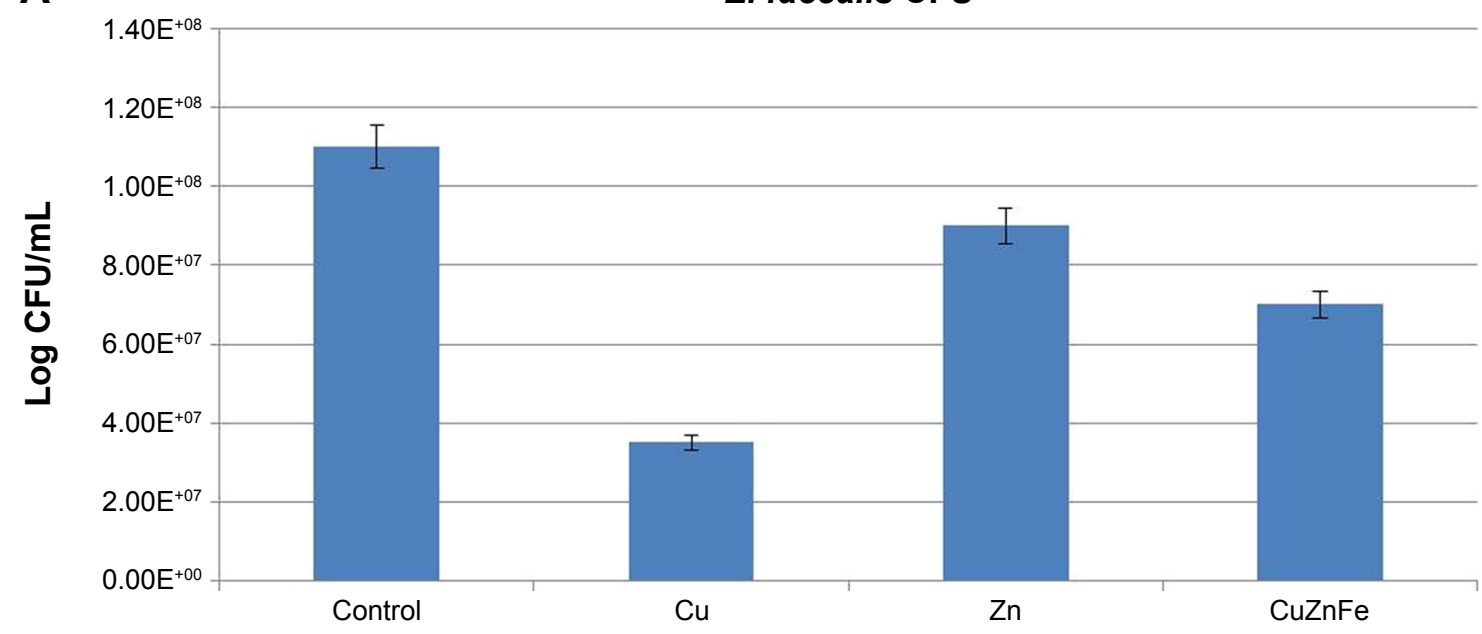

B

E. coli CFU

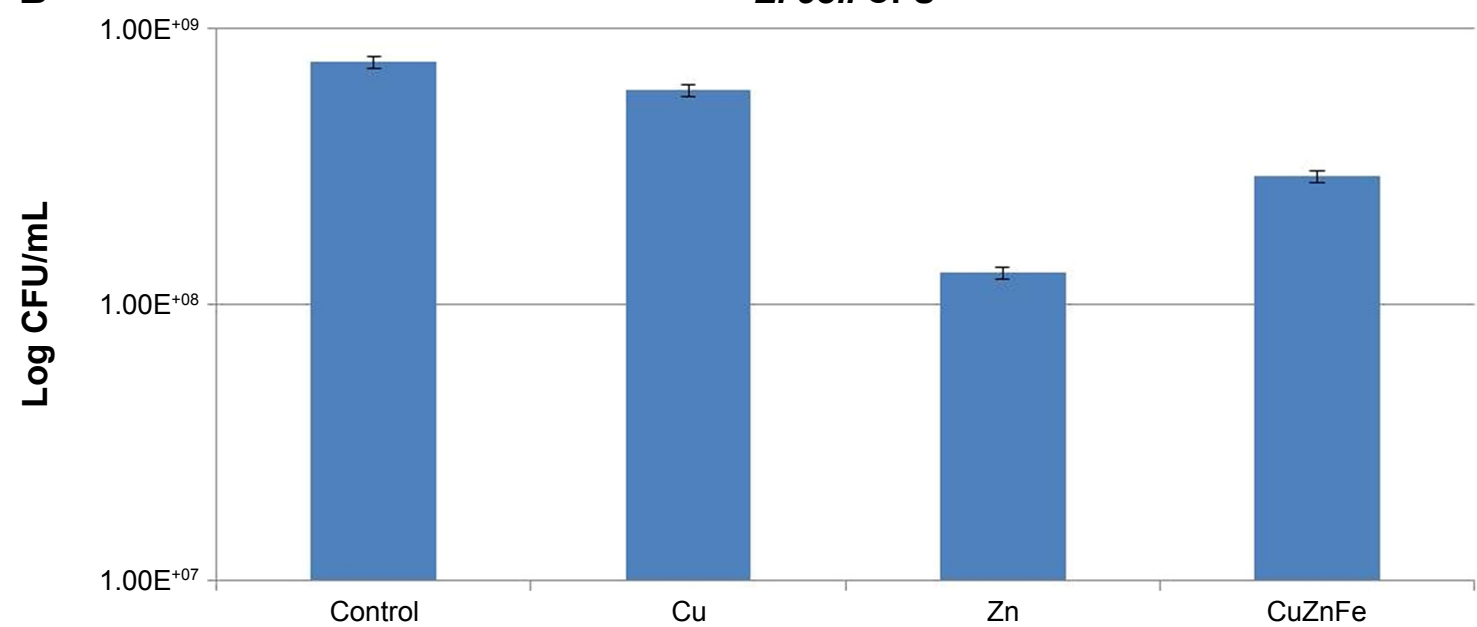

Figure 8 Colony-forming units (CFU) for (A) Enterococcus faecalis (E. faecalis) and (B) Escherichia coli (E. coli) after incubation in nutrient broth overnight with no nanoparticles (NPs) or in the presence of $150 \mu \mathrm{g} / \mathrm{mL}$ of metal oxides NPs.

possess an additional outer membrane constructed mainly of negatively charged lipopolysaccharide molecules (LP).

In the present study, we observed that $\mathrm{CuZnFe}$ oxide NPs have detrimental effects on E. coli (gram-negative) compared to the effects caused by individual $\mathrm{CuO}$ and $\mathrm{ZnO}$ NPs. CuZnFe oxide NPs were also found to be more bactericidal than $\mathrm{ZnO}$ against $E$. faecalis (gram-positive), but $7 \%$ lower than $\mathrm{CuO}$ NPs. CuZnFe oxide NPs in this study form agglomerates with an average size of $\sim 128 \mathrm{~nm}$. It seems that these large agglomerates are less likely to pass through the cell wall to cause bacterial damage from the interior, and thus penetration is unlikely the main mechanism for antibacterial activity of $\mathrm{CuZnFe}$ oxide NPs. But it can slowly release metal ions capable of crossing into membranes and disrupt cellular processes from inside the cell. ${ }^{12,29}$ Another potential mechanism that might explain susceptibility of E. coli to $\mathrm{CuZnFe}$ oxide NPs is its higher affinity to LP, ${ }^{36}$ the main constituent of the outer membrane of gram-negative bacteria. The physical interaction between $\mathrm{CuZnFe}$ oxide NPs and bacterial cells can disrupt the cell wall structure, leading to malfunction and to finally bacterial death. Thus, a bactericidal activity of trimetal oxide NPs can be attributed to a variety of properties. We assumed that $\mathrm{CuZnFe}$ oxide NPs are characterized differently from individual metal NPs due to their size and surface chemistry. The exact mechanisms for antibacterial activity of $\mathrm{CuZnFe}$ oxide NPs are still unclear and more investigation is required.

The individual $\mathrm{CuONPs}$ had a greater impact on $E$. faecalis than on E. coli as assessed by cell death analysis (Figure 5). This is consistent with the findings of Ruparelia et al, ${ }^{7}$ who also reported that $\mathrm{CuO}$ NPs affect various strains of $E$. coli differently. In this matter, they concluded that gram-negative bacteria may be affected less by the $\mathrm{CuO}$ NPs, which might involve more complex mechanisms. Also, Premanathan et a ${ }^{37}$ found that gram-negative bacteria can be more resistant to $\mathrm{CuO}$ NPs than gram-positive bacteria. Of the different metals, 
$\mathrm{Cu}$ and $\mathrm{CuO}$ have been widely used as cheap and effective bacteriostatic agents for sterilizing liquids and biological tissues. ${ }^{32}$ It is important to note that some bacterial species are more sensitive to particular NPs than are others. ${ }^{26,32}$ Therefore, $\mathrm{CuO}$ NP may be a promising antibacterial agent in combination with other metallic NPs. By contrast, we used ZnO NPs and showed a greater effect on the viability of the gramnegative $E$. coli than on the gram-positive $E$. faecalis, a result that may correspond to the thickness of the cell walls.

The results of CFU measurements indicated that the action of $\mathrm{CuZnFe}$ oxide NPs on $E$. coli was non-permanent, by showing recovery of the treated cells (Figure 8). The CFU results also indicated that the $\mathrm{CuZnFe}$ oxide NPs had a similar effect on E. coli and E. faecalis and an intermediate effect compared to the effects by the $\mathrm{CuO}$ or $\mathrm{ZnO}$ NPs. Trimetal ( $\mathrm{CuZnFe}$ ) oxide NPs affected biofilm formation to a lesser degree than did individual $\mathrm{ZnO}$ and $\mathrm{CuO}$ NPs. This indicates that the reduction in biofilm formation was not a result of cell loss but of the NP effect. Reduced biofilm formation with exposure to $\mathrm{CuO}$ and $\mathrm{ZnO}$ correlated with cell death and reduced CFU count for both E. faecalis and E. coli, but this was not the case with $\mathrm{CuZnFe}$ oxide NPs. The reduced disruption of biofilm formation by $\mathrm{CuZnFe}$ oxide NPs might result from the disruption in quorum sensing rather than from the effect of NPs. Quorum sensing has been established as an important factor in biofilm formation in both gram-positive and gram-negative bacteria. ${ }^{38-41}$ However, more investigation is needed on the effect of metallic NPs on biofilm inhibition to fully understand the reason. Also, there is a need to know how biofilm inhibition occurs and what antibacterial mechanisms are involved.

To sum up, the implication from the results of our study is that trimetal $(\mathrm{CuZnFe})$ oxide NPs can be very useful in terms of antibacterial activity. Overall, the effect of $\mathrm{CuZnFe}$ oxide NPs on E. faecalis and E. coli lies between the effect of $\mathrm{CuO}$ and $\mathrm{ZnO}$ NPs. Therefore, we assume that the cytotoxicity of $\mathrm{CuZnFe}$ oxide NPs may be also between that of pure $\mathrm{ZnO}$ and $\mathrm{CuO}$ nanoparticles. This might be explained by the buffering caused by the presence of ferric oxide $\left(\mathrm{Fe}_{2} \mathrm{O}_{3}\right)$ in the trimetal NPs, leading to a reduced toxic effect. Also, it has to be emphasized that the presence of $\mathrm{Fe}_{2} \mathrm{O}_{3}$ NPs causes less toxicity than other metal oxide NPs, as previously suggested by Azam et al. ${ }^{17}$ However, further investigations are needed to determine whether these hypotheses are true or not. Finally, with the current drug-delivery techniques, $\mathrm{CuZnFe}$ oxide NPs could be administered to the infected site for in situ treatment. These NPs could also be used as coating agents for various medical devices to prevent attachment and growth of a wide range of pathogenic bacteria.

\section{Conclusion}

The antimicrobial effect of the trimetal $(\mathrm{CuZnFe})$ oxide NPs on both gram-positive and gram-negative bacteria was studied and compared with that of $\mathrm{ZnO}$ and $\mathrm{CuO}$ NPs. The CuZnFe oxide NPs were characterized using XRD, HRTEM, and EDX. HRTEM images showed that the NPs are almost spherical with a tendency to agglomerate. On the basis of several HRTEM images taken at different angles, the average particle size of CuZnFe oxide NPs was estimated to be $42 \pm 2 \mathrm{~nm}$. Analysis of $E$. coli cell death demonstrated that $\mathrm{CuZnFe}$ oxide NPs have greater antibacterial efficiency than pure $\mathrm{ZnO}$ and $\mathrm{CuO}$ NPs. On the other hand, the effect of CuZnFe oxide NPs on E. faecalis was between that of $\mathrm{ZnO}$ and $\mathrm{CuO}$. The monitoring of biofilm formation by both bacterial cells in the presence of the NPs used in these experiments revealed that the efficiency of $\mathrm{CuZnFe}$ oxide NPs in inhibiting biofilm formation is comparable to that of pure $\mathrm{ZnO}$ and $\mathrm{CuO}$ NPs. However, the number of CFUs showed that the effect of CuZnFe oxide NPs on cell viability was between that of the $\mathrm{ZnO}$ and $\mathrm{CuO}$ NPs.

\section{Acknowledgments}

This work was supported by King Saud University, Deanship of Scientific Research, College of Science Research Center, Kingdom of Saudi Arabia.

\section{Author contributions}

KEA, HSA, and AAN designed the study and the experiments, and wrote the manuscript. HSA and AAN carried out the biological part of the experiments. KEA, RW, AMA, and AME synthesized and characterized the NPs. All authors helped discuss, interpret, and shape the research and the manuscript, contributed toward data analysis, drafting and critically revising the paper, gave final approval of the version to be published, and agree to be accountable for all aspects of the work.

\section{Disclosure}

The authors report no conflicts of interest in this work.

\section{References}

1. Ventola CL. The antibiotic resistance crisis: part 1: causes and threats. P T. 2015;40(4):277-283.

2. Alanis AJ. Resistance to antibiotics: are we in the post-antibiotic era? Arch Med Res. 2005;36(6):697-705.

3. Davies J, Davies D. Origins and evolution of antibiotic resistance. Microbiol Mol Biol Rev. 2010;74(3):417-433.

4. Riley MA, Robinson SM, Roy CM, Dennis M, Liu V, Dorit RL. Resistance is futile: the bacteriocin model for addressing the antibiotic resistance challenge. Biochem Soc Trans. 2012;40(6):1438-1442. 
5. Bjarnsholt $\mathrm{T}$. The role of bacterial biofilms in chronic infections. APMIS Suppl. 2013;121(Suppl s136):1-58.

6. Shen Y, Zhao J, de la Fuente-núñez C, et al. Experimental and theoretical investigation of multispecies oral biofilm resistance to chlorhexidine treatment. Sci Rep. 2016;6:27537.

7. Ruparelia JP, Chatterjee AK, Duttagupta SP, Mukherji S. Strain specificity in antimicrobial activity of silver and copper nanoparticles. Acta Biomater. 2008:4(3):707-716.

8. Jiang W, Mashayekhi H, Xing B. Bacterial toxicity comparison between nano- and micro-scaled oxide particles. Environ Pollut. 2009 157(5):1619-1625.

9. Dizaj SM, Lotfipour F, Barzegar-Jalali M, Zarrintan MH, Adibkia K. Antimicrobial activity of the metals and metal oxide nanoparticles. Mater Sci Eng C Mater Biol Appl. 2014;44:278-284.

10. Gu H, Ho P, Tong E, Wang L, Xu B. Presenting vancomycin on nanoparticles to enhance antimicrobial activities. Nano Lett. 2003;3(9): 1261-1263.

11. Huang Z, Zheng X, Yan D, et al. Toxicological effect of ZnO nanoparticles based on bacteria. Langmuir. 2008;24(8):4140-4144.

12. Hayden SC, Zhao G, Saha K, et al. Aggregation and interaction of cationic nanoparticles on bacterial surfaces. J Am Chem Soc. 2012;134(16): 6920-6923.

13. Raghupathi KR, Koodali RT, Manna AC. Size-dependent bacterial growth inhibition and mechanism of antibacterial activity of zinc oxide nanoparticles. Langmuir. 2011;27(7):4020-4028.

14. Liu Y, He L, Mustapha A, Li H, Hu ZQ, Lin M. Antibacterial activities of zinc oxide nanoparticles against Escherichia coli O157:H7. J Appl Microbiol. 2009;107(4):1193-1201.

15. Shakerimoghaddam A, Ghaemi EA, Jamalli A. Zinc oxide nanoparticle reduced biofilm formation and antigen 43 expressions in uropathogenic Escherichia coli. Iran J Basic Med Sci. 2017;20(4):451-456.

16. Jones N, Ray B, Ranjit KT, Manna AC. Antibacterial activity of ZnO nanoparticle suspensions on a broad spectrum of microorganisms FEMS Microbiol Lett. 2008;279(1):71-76.

17. Azam A, Ahmed AS, Oves M, Khan MS, Habib SS, Memic A. Antimicrobial activity of metal oxide nanoparticles against Gram-positive and Gram-negative bacteria: a comparative study. Int J Nanomedicine. 2012;7:6003

18. Hernández-Sierra JF, Ruiz F, Cruz Pena DC, et al. The antimicrobial sensitivity of Streptococcus mutans to nanoparticles of silver, zinc oxide, and gold. Nanomedicine. 2008;4(3):237-240.

19. Fang M, Chen JH, Xu XL, Yang PH, Hildebrand HF. Antibacterial activities of inorganic agents on six bacteria associated with oral infections by two susceptibility tests. Int J Antimicrob Agents. 2006;27(6): 513-517.

20. Reddy KM, Feris K, Bell J, Wingett DG, Hanley C, Punnoose A. Selective toxicity of zinc oxide nanoparticles to prokaryotic and eukaryotic systems. Appl Phys Lett. 2007;90(21):213902-2139023.

21. Heng BC, Zhao X, Xiong S, Ng KW, Boey FY, Loo JS. Toxicity of zinc oxide $(\mathrm{ZnO})$ nanoparticles on human bronchial epithelial cells (BEAS-2B) is accentuated by oxidative stress. Food Chem Toxicol. 2010;48(6): 1762-1766.

22. Ingle AP, Duran N, Rai M. Bioactivity, mechanism of action, and cytotoxicity of copper-based nanoparticles: a review. Appl Microbiol Biotechnol. 2014;98(3):1001-1009.
23. Das R, Gang S, Nath SS, Bhattacharjee R. Linoleic acid capped copper nanoparticles for antibacterial activity. J Bionanosci. 2010; $4(1-2): 82-86$

24. $\mathrm{Xu} \mathrm{J}, \mathrm{Ji} \mathrm{W}$, Shen Z, et al. Preparation and characterization of $\mathrm{CuO}$ nanocrystals. J Solid State Chem. 1999;147(2):516-519.

25. Chen Z, Meng H, Xing G, et al. Acute toxicological effects of copper nanoparticles in vivo. Toxicol Lett. 2006;163(2):109-120.

26. Prabhu BM, Ali SF, Murdock RC, Hussain SM, Srivatsan M. Copper nanoparticles exert size and concentration dependent toxicity on somatosensory neurons of rat. Nanotoxicology. 2010;4(2):150-160.

27. Siddiqui MA, Alhadlaq HA, Ahmad J, Al-Khedhairy AA, Musarrat J, Ahamed M. Copper oxide nanoparticles induced mitochondria mediated apoptosis in human hepatocarcinoma cells. PLoS One. 2013; 8(8):e69534

28. Shanthala V, Devi SS, Murugendrappa M. Synthesis, characterization and DC conductivity studies of polypyrrole/copper zinc iron oxide nanocomposites. J Asian Ceramic Soc. 2017;5(3):227-234.

29. Gordon T, Perlstein B, Houbara O, Felner I, Banin E, Margel S. Synthesis and characterization of zinc/iron oxide composite nanoparticles and their antibacterial properties. Colloids Surf A. 2011;374(1):1-8.

30. Costerton JW, Stewart PS, Greenberg EP. Bacterial biofilms: a common cause of persistent infections. Science. 1999;284(5418):1318-1322.

31. Das T, Manefield M. Pyocyanin promotes extracellular DNA release in Pseudomonas aeruginosa. PLoS One. 2012;7(10):e46718.

32. Ashfaq M, Verma N, Khan S. Copper/zinc bimetal nanoparticlesdispersed carbon nanofibers: a novel potential antibiotic material. Mater Sci Eng C Mater Biol Appl. 2016;59:938-947.

33. Ingle A, Gade A, Pierrat S, Sonnichsen C, Rai M. Mycosynthesis of silver nanoparticles using the fungus Fusarium acuminatum and its activity against some human pathogenic bacteria. Curr Nanosci. 2008; 4(2):141-144.

34. Wahab R, Khan F, Bing Yang Y, et al. Zinc oxide quantum dots: multifunctional candidates for arresting $\mathrm{C} 2 \mathrm{C} 12$ cancer cells and their role towards caspase 3 and 7 genes. RSC Adv. 2016;6(31):26111-26120.

35. Wahab R, Siddiqui MA, Saquib Q, et al. ZnO nanoparticles induced oxidative stress and apoptosis in HepG2 and MCF-7 cancer cells and their antibacterial activity. Colloids Surf B Biointerfaces. 2014;117:267-276.

36. Zhang L, Jiang Y, Ding Y, Povey M, York D. Investigation into the antibacterial behaviour of suspensions of $\mathrm{ZnO}$ nanoparticles $(\mathrm{ZnO}$ nanofluids). J Nanopart Res. 2007;9(3):479-489.

37. Premanathan M, Karthikeyan K, Jeyasubramanian K, Manivannan G. Selective toxicity of $\mathrm{ZnO}$ nanoparticles toward Gram-positive bacteria and cancer cells by apoptosis through lipid peroxidation. Nanomedicine. 2011;7(2):184-192.

38. Cvitkovitch DG, Li YH, Ellen RP. Quorum sensing and biofilm formation in Streptococcal infections. J Clin Invest. 2003;112(11):1626.

39. Hentzer M, Riedel K, Rasmussen TB, et al. Inhibition of quorum sensing in Pseudomonas aeruginosa biofilm bacteria by a halogenated furanone compound. Microbiology. 2002;148(Pt 1):87-102.

40. Kong KF, Vuong C, Otto M. Staphylococcus quorum sensing in biofilm formation and infection. Int J Med Microbiol. 2006;296(2):133-139.

41. Mohamed JA, Huang W, Nallapareddy SR, Teng F, Murray BE. Influence of origin of isolates, especially endocarditis isolates, and various genes on biofilm formation by Enterococcus faecalis. Infect Immun. 2004; 72(6):3658-3663.
International Journal of Nanomedicine

\section{Publish your work in this journal}

The International Journal of Nanomedicine is an international, peerreviewed journal focusing on the application of nanotechnology in diagnostics, therapeutics, and drug delivery systems throughout the biomedical field. This journal is indexed on PubMed Central, MedLine, CAS, SciSearch ${ }^{\circledR}$, Current Contents ${ }^{\circledR} /$ Clinical Medicine,

\section{Dovepress}

Journal Citation Reports/Science Edition, EMBase, Scopus and the Elsevier Bibliographic databases. The manuscript management system is completely online and includes a very quick and fair peer-review system, which is all easy to use. Visit http://www.dovepress.com/ testimonials.php to read real quotes from published authors. 